\title{
Relationship Between Social Culture, Industry 4.0, and Organizational Performance in the Context of Emerging Economies
}

\author{
Iliana E. Aguilar-Rodríguez ${ }^{1}$ (D), César A. Bernal-Torres ${ }^{2}$ (D) Juan C. Aldana-Bernal ${ }^{3}$ (D), \\ Andrés G. Acosta-Aguinaga ${ }^{4}$ (D), Carlos H. Artieda-Cajilema ${ }^{1}$ (D), Priscila Chalá1 (iD) \\ ${ }^{1}$ Universidad de Las Américas (Ecuador) \\ ${ }^{2}$ Universidad de La Sabana (Colombia) \\ ${ }^{3}$ Universidad Nacional de Colombia (Colombia) \\ ${ }^{4}$ Escuela de Educación Superior Tecnológica Privada Toulouse Lautrec (Peru) \\ iliana.aguilar@udla.edu.ec, cesar.bernal@unisabana.edu.co,jcaldanab@unal.edu.co,aacosta@tts.edu.pe, \\ carlos.artieda@udla.edu.ec,priscila.chala@udla.edu.ec
}

Received: April 2021

Accepted: May 2021

\section{Abstract:}

Purpose: Was examined the relationship between social culture, Industry 4.0 technologies, and organizational performance in companies from emerging countries.

Design/methodology/approach: Were chose medium and large companies from emerging Latin American economies. Colombia and Peru as the most advanced economies, and Ecuador for being in the first phase of growth. It was data from 428 workers collected through online surveys. The data analysis was carried out using a Structural Equation Model.

Findings: The results indicated a relationship between Industry 4.0 technologies and organizational performance and social culture and organizational performance. Furthermore, social culture does not mediate the relationship between Industry 4.0 technologies and organizational performance. Also found differences among countries. Evidence is provided that Industry 4.0 technologies and social culture lead to better organizational performance.

Practical implications: This study showed that, in the context of analysis, the level of maturity regarding the use of 4.0 technologies of medium and large companies is still incipient. Provides (1) information on cultural differences, mainly in the dimensions of Masculinity, Power Distance, and Individualism; and (2) guidelines on the use of Industry 4.0 technologies and their implication in organizational performance.

Originality/value: The research results provide knowledge of the relationship between 4.0 technologies, social culture, and organizational performance in the context of emerging economies where the subject has been little investigated.

Keywords: national culture, culture dimensions, organizational performance, medium-sized and large businesses, latin america, emerging economies, digital transformation

\section{To cite this article:}

Aguilar-Rodríguez, I.E., Bernal-Torres, C.A., Aldana-Bernal, J.C., Acosta-Aguinaga, A.G., Artieda-Cajilema, C.H. \& Chalá, P. (2021). Relationship between social culture, industry 4.0, and organizational performance in the context of emerging economies. Journal of Industrial Engineering and Management, 14(4), 750-770.

https://doi.org/10.3926/jiem.3560 


\section{Introduction}

Industry 4.0 was introduced in Germany in 2011 as a high-tech strategy to prepare and strengthen the industrial sector for future production requirements (Dash, Mohapatra, Das \& Sahoo, 2018; Ghobakhloo, 2018). Various studies have emphasized the automation of production processes, the digitization of the value chain, and its interconnection between people, objects, and systems (Dorst, Glohr, Hahn, Knafla, Lenk, Meyerholt et al., 2015; Liao, Deschamps, Loures \& Ramos, 2017; Weyer, Schmitt, Ohmer \& Gorecky, 2015), contributing to the development of products and services (Dalenogare, Benitez, Ayala \& Frank, 2018; Frank, Dalenogare \& Ayala, 2019) and allowing a new way of working (Stock, Obenaus, Kunz \& Kohl, 2018). These help to manufacture management (Fettermann, Sá Cavalcante, Tortorella \& de Almeida, 2018), as well as business model innovation (Nascimento, Alencastro, Quelhas, Caiado, Garza-Reyes, Lona et al., 2019) and the implementation of solutions in logistics (Witkowski, 2017).

For the year 2020 alone, the projection of devices linked to Industry 4.0 was between 20 and 46 billion, benefiting manufacturers, suppliers and consumers (Bizanis \& Kuipers, 2016; Kayalvizhi, Amirtha Sughi \& Divyalakshmi, 2019). Although technological changes are becoming increasingly rapid and unpredictable, organizations face an improvement in their productivity daily (Taddeo, Simboli, Di Vincenzo \& Ioppolo, 2019), and they must react in an agile way to the new challenges and opportunities that arise in environments dominated by intelligent technologies (Grzybowska \& Lupicka, 2017; Tortorella, Cawley Vergara, Garza-Reyes \& Sawhney, 2020).

However, despite the explained antecedents, Industry 4.0 technologies have been applied chiefly for production activities, implemented in companies in developed economies, such as the automotive and service industries (Demeter, Losonci, Marciniak, Nagy, Móricz, Matyusz et al., 2020; Ghobakhloo, 2018). Very little has been done in emerging economies such as the Latin American and Caribbean countries (LAC) (Dalenogare et al., 2018; Frank et al., 2019). Besides, understanding how these technologies are linked to the workers' culture is an issue that has not yet been addressed, and that is relevant since globalization has made cultural values constantly change. Technology is conclusive in the development of social structures (Salehan, Kim \& Lee, 2018). Additionally, it may reflect national cultures in employee culture.

Although research has been carried out that analyzes the relationship between culture and technological acceptance (Hasan \& Ditsa, 1999; Salehan et al., 2018; Srite, 2006; Tarhini, Hone \& Liu, 2015; Tarhini, Hone, Liu \& Tarhini, 2017), the role of social culture in the use of Industry 4.0 technologies adopted by organizations in emerging economies is not known. In addition, how this influences their organizational performance, given that the culture of the employees positively or negatively affects the firm (Beugelsdijk \& Welzel, 2018; Minkov, 2018), mainly because of patterns of thought and behaviour are involved (Hofstede, 2001b). Other studies show that models focused on economies of scale are being replicated (Dalenogare et al., 2018), who have neglected the importance of intellectual capital and the acquisition of new skills and abilities in workers (Wei, Song \& Wang, 2017) to be replaced by production automation (Coldwell, 2019; Luthra \& Mangla, 2018; Taddeo et al., 2019).

In any case, Industry 4.0 requires organizations to create disruptive business models and decision-making processes that impact the customer experience (Lee, Huang \& Ashford, 2018; Wang, Wan, Li \& Zhang, 2016) and that demand greater competitiveness and improvement of work (Drewniak \& Gabryś, 2017; Wang et al., 2016). What is not clear is whether this would provide sustainable business performance (Haseeb, Hussain, Ślusarczyk \& Jermsittiparsert, 2019), with business opportunities that ensure manufacturing in advanced economies with high added value (Dassisti, Giovannini, Merla, Chimienti \& Panetto, 2019) and, therefore, with a positive impact on the well-being of the countries (Ganju, Pavlou \& Banker, 2016).

In this sense, this study analyzes the relationship between (1) Industry 4.0 technologies, social culture, and organizational performance, and (2) the mediation of social culture with Industry 4.0 technologies and organizational performance. Medium and large companies from Ecuador, Colombia, and Peru have been considered the analysis unit since Ecuador is in the first growth phase. At the same time, Colombia and Peru are more advanced emerging economies. Also, they are countries with similar organizational structures and similarities in their inhabitants' cultural dimensions (Hofstede Centre, 2021). Simultaneously, are restrictions in knowledge due to the lack of data regarding these companies that indicate the variables' horizon to be studied. For this reason, this 
article provides relevant evidence for companies in emerging economies on the importance of the use of Industry 4.0 Technologies in organizational performance, influenced by the social culture of their workers. Organizations, therefore, should encourage investment in new technologies, reduce the competitive and comparative gap with industrialized countries, and understand that, in a culturally diverse environment, the performance of firms can increase with the access and use of those technologies, especially those of digital transformation.

The article defines a theoretical framework on the study variables and their relationship to establish the proposed research model's respective hypotheses. Then, the methodology is presented, which details the population and sample, the construction of the measuring instrument, and the data collected. Subsequently, the most relevant results, discussion, and conclusions are presented to propose the study's implications, limitations, and future research recommendations.

\section{Literature Review and Development of Hypotheses}

\subsection{Social Culture and Technologies of Industry 4.0}

Organizations face new challenges because, although Industry 4.0 creates many opportunities for companies, at the same time, it generates challenges derived from automation and digitization (Grzybowska \& Lupicka, 2017; Wollschlaeger, Sauter \& Jasperneite, 2017). Hofmann and Rüsch (2017) argue that Industry 4.0 affects the business by transforming how products are designed, manufactured, delivered, and paid. Therefore, in making business decisions, human and technological resources are essential, and as well the culture is possessed by the individuals who are part of said organization. Thus, managers must know their collaborators' culture to understand whether a technology will be accepted and develop strategies to overcome their cultural resistance. These are decisive in planning, designing, introducing, and implementing new technologies (Gallivan \& Srite, 2005; Srite, 2006; Tarhini et al., 2015, 2017). Also, the need for culture within organizations to promote creativity and support innovation is highlighted (Barczyk, Rarich, Klonowsky \& Angriawan, 2019; Cheung, Wong \& Lam, 2012; Huang, Teo, SánchezPrieto, García-Peñalvo \& Olmos-Migueláñez, 2019).

For Hofstede (1980), culture is the collective mental programming that defines the rules, rituals, norms, and procedures (Hofstede, 1983; Van Muijen \& Koopman, 1994), measured through cultural dimensions: (1) Power Distance Index (PDI); (2) Uncertainty Avoidance (UAI); (3) Individualism/Collectivism (IDV); Masculinity/Femininity (MAS) (Hofstede, 2011), by which it is established that people have different value orientations, which cause different behaviours. Then, the cultural differences of the workers could affect the effectiveness of the companies (Baumgartner \& Weijters, 2017; Karahanna, Evaristo \& Srite, 2001); because in these cultures, diverse social groups co-exist, with members that come from different regions, generations, and socioeconomic groups (Kirkman, Lowe \& Gibson, 2017). For this, Srite (2006) suggested that, for example, group training and roundtables might be more appropriate in collectivist cultures, while online training might work better in individualistic cultures. Thus, workers should learn to interact in different group cultures (racial, ethnic, linguistic, religious/ideological, social class, and gender) (Slimbach, 1993).

Van Muijen and Koopman (1994) identified that national culture's effects lead to the generation of organizational cultures centred on rules or the pyramid model in specific industries. Simultaneously, in others, the orientation towards innovation predominates, where the tasks that traditionally have corresponded to management have gradually been replaced by Information and Communication Technologies (ICT). Thus, managers' managerial competencies are measured from the technical context and from the social context that includes, as they refer Grzybowska and Lupicka (2017), transferring knowledge, teamwork, and leadership skills. Srisathan, Ketkaew, and Naruetharadhol (2020) emphasized that culture is related to innovation through organizational sustainability and is supported by transformative leadership, organizational climate, teamwork, and employee empowerment.

Recent research found that IDV, MAS, PDI, and UAI dimensions explain behavioural intentions in an intercultural context (Huang et al., 2019; Tarhini et al., 2015; Tarhini et al., 2017). Vrânceanu and Iorgulescu (2016) also suggested that even though people can comply with organizational and cultural norms, they prioritize cultural norms. Salehan et al. (2018) also argued that globalization has caused cultural values to change, and technology is conclusive in developing social structures, achieving higher IDV and lower PDI. Only in Latin America, countries with a high power distance index, such as Peru, are being structurally transformed (Carballo \& Moreno, 2013). A 
masculinity rate in the entire region of $106.8 \%$ is projected by 2050 (CELADE, Population Division of ECLAC, Revision and United Nations \& Department of Economic and Social Affairs, 2019). On the other hand, although it has been found that in the different areas, countries like Canada are more receptive than China in continuous improvement and that the organizational culture is more influential than the national culture, as well as the leadership and vision of the company, are stronger than cultural attributes, social culture is still more relevant.

Therefore, culture is a determinant of organizational success because it can foster innovation, risk-taking, and flexibility in response to its environment's uncertainty (Barczyk et al., 2019). He and Lee (2020) found in some companies that specific innovation characteristics influence their diffusion process when UAI is high, while when IDV and UAI are low, their effect is restricted. However, Industry 4.0 technologies, for the most part, have been related to the development of essential activities and have been implemented in companies with a highly competitive global environment and not in emerging economies (for example, the automotive industry and companies of services) (Demeter et al., 2020; Ghobakhloo, 2018). Mazali (2018), in his study in Italian factories, found that people's participation in organizational transformation processes is related to culture, digital society, and Industry 4.0; that is, workers can enter the operations of individualization of work and spread a culture that assigns responsibility to the individual at the expense of a collective identity.

It becomes prominent, then, to consider that social culture in organizations has a particular influence on the exchange of knowledge for commercial systems' success, becoming an essential part of the use of Industry 4.0. Besides, these affect the socio-cultural levels of the employees, since they intervene in the way they learn, being their behaviour what determines their organizational performance (Tortorella et al., 2020). In emerging economies, learning in the workplace, among employees at all hierarchical levels, can generate agility and competitiveness for sustainable business (Singh, Cervai \& Kekäle, 2016).

\subsection{Industry 4.0 Technologies and Organizational Performance}

The literature reveals that Industry 4.0 has the fundamental objective of improving organizational performance (Kamble, Gunasekaran \& Dhone, 2020; Lasi, Fettke, Kemper, Feld \& Hoffmann, 2014; Luthra \& Mangla, 2018; Quezada, Chiu, Gouvea da Costa \& Tan, 2017; Stock \& Seliger, 2016; Yadegaridehkordi, Nilashi, Shuib, Nasir, Asadi, S., Samad \& Awang, 2020). By Yunis, Tarhini and Kassar (2018), both innovation and the use of ICT resources can generate better organizational performance by enabling economic growth and social change.

High competition in supply chains has led organizations to upgrade their manufacturing systems to smart levels, generating more flexible and dynamic processes (Shen \& Norrie, 2001). Thus, 4.0 technologies can influence the entire business system in new tools for the design, production, delivery, and dispatch of products (Luthra \& Mangla, 2018). Despite this, Singh, Kumar and Chand (2019) state that most organizations use Industry 4.0 technologies only in certain parts of their supply chain, causing it to be less coordinated and causing a decrease in resources; situation also identified by Dalenogare et al., (2018), especially in countries with emerging economies when compared to developed countries. For this reason, the need for managers and a more qualified labour force with special skills become evident since the processes must respond flexibly to the interruptions that may generate (Grzybowska \& Lupicka, 2017). Thus, although there is an implicit relevance in using Industry 4.0 technologies, employees' active participation in solving problems plays a crucial role in better performance (Tortorella, Miorando, Caiado, Nascimento \& Portioli Staudacher, 2018; Tortorella et al., 2020).

Although Industry 4.0 has increased the productivity of companies with smart grids through efficiency in the use of resources (Brettel, Friederichsen, Keller \& Rosenberg, 2014; Taddeo et al., 2019) and has presented broad access to information about the organization (Gawankar, Gunasekaran \& Kamble, 2020; Gupta \& George, 2016), it has also generated low wages and unemployment in workers, which have affected their well-being (Luthra \& Mangla, 2018; Taddeo et al., 2019). In the face of organizational problems, managers have pressured their employees to find solutions in the short term to maintain profitability (Coldwell, 2019). Nevertheless, Stachová, Papula, Stacho and Kohnová (2019) stated that companies' sustainability orientation towards intellectual capital must give in the long term. Incorporating new technologies also requires employees' unique skills and abilities (Wei et al., 2017). Industry 4.0 configures new business models and decision-making processes, and the customer experience (Lee et al., 2018; 
Wang et al., 2016). The classical methods of optimizing production processes are insufficient for the current requirements and need new assumptions to rebuild (Drewniak \& Gabryś, 2017).

To this is added what is stated by Načinović Braje, Klindžić and Galetić (2019) in their research carried out in Croatia, that as a collectivist society, companies offer individual variable pay, sales commissions, and occasional bonuses to their employees as an incentive to their performance in the organization. Also, Saad and Abbas (2018), in their study of Western work cultures, found that organizational culture through organizational values, routines, and distinctive aspects of social culture allows companies to create solid competitive advantages by influencing organizational performance.

\subsection{Technologies of Industry 4.0, Social Culture and, Organizational Performance}

For companies to improve their organizational performance when they implement Industry 4.0 technologies, they must consider the various aspects of human performance and their employees' culture (Kamble et al., 2020). Shamim, Cang, Yu, Li, Chen and Yao (2019) contribute to the importance that companies from emerging economies should give to Industry 4.0. They suggest the need to correctly combine leadership, human talent management, technology, and culture with learning and implementing these technologies to influence management practices. However, various studies have revealed that the automation of processes could affect employment and increase wage inequality (Acemoglu, 2002; Atasoy, 2013). Rapid industrialization also contributes to the degradation of the workforce's health and safety (Coldwell, 2019; Luthra \& Mangla, 2018; Taddeo et al., 2019). Still, the adoption of Industry 4.0 has a positive impact on countries' well-being (Ganju et al., 2016).

For example, with the Internet of Things (IoT), organizations will have sustainable business performance (Haseeb et al., 2019). However, for Luthra and Mangla (2018), financial constraints, lack of competition, and even little administrative support are the most common barriers to its implementation in the context of emerging economies. Another example is the recent findings of multinational manufacturing companies. They have recognized the effect that Industry 4.0 has on digital transformation, redefining how these companies have taken advantage of their ownership-location-internalization benefits (Das \& Dey, 2021). Although there is no method by which manufacturing companies can select a large number of improvement projects (Sophie, Pellerin, Bellemare \& Perrier, 2020) because studies tend to focus on the evaluation and implementation of a single technology, while the transformation of an intelligent plant requires the consolidation and coordination of many initiatives to achieve a global goal. For its part, Borowski (2021) affirms that digitization in the energy sector has exceeded the traditional ranges of productivity improvement of three to five percent per year, with a potential cost improvement of more than $25 \%$, which motivates companies to increase energy efficiency through the implementation of state-of-the-art innovative technical and technological solutions. In this way, digital ecosystems must depend on stakeholders to form networks of collective competence (Markova, Zyuzina \& Krovopuskov, 2021).

On the other hand, Srite's (2006) contributions showed that if workers use a technology that requires less effort, they could use it more frequently because they can feel comfortable with their work and have fewer frustrations. However, the adoption of technology can be reinforced by the role played by social culture. If solidarity prevails, it will be easier to integrate new technologies that support business strategies (Hoffman \& Klepper, 2000). Besides, when cultural values such as IDV prevail in workers, this affects the MAS and UAI, making them less sensitive to their team and more concerned about their professional growth (Roy, 2020). Also, IDV, UAI, MAS, and LTO were significant factors that affect administrative knowledge adoption (Usoro \& Abiagam, 2018).

Dastmalchian, Bacon, McNeil, Steinke, Blyton, Satish Kumar et al. (2020), with comparative data between employers and employees, found that social culture moderates the relationship between human resource management practices and organizational performance (although the IDV and PDI dimensions were not moderating). Additionally, management practices that improve job opportunities were less effective in high PDI cultures. There were combinations of high-performance work systems with Ability - Motivation - Opportunity practices that overcame social culture and improved organizational performance for other countries. For Usoro and Abiagam (2018), IDV and PDI were not significant in adopting organizational knowledge. While Gebauer, Edvardsson and Bjurko (2010) showed a positive association between service orientation of culture and business 
performance and moderating effects of the type of organizational structure. Rojas (2019) identified that native cultures have a moderating impact on views of inclusion and diversity.

Lee, Lee, Kim and Lee (2017) found in Korean and Japanese manufacturing companies that agility (organizational capacity) positively affected organizational performance (financial and non-financial), mainly due to the rapid change in the business environment. Also, Muafi and Kusumawati (2020) established that corporate performance would be higher, while the degree of alignment between the imitation/innovation strategy and the hierarchical/adhocratic culture is also higher. They also emphasized that human capital strengthens the imitation strategy with the hierarchical culture for more excellent organizational performance, which did not happen with the innovation strategy. In this way, studies that involve social culture as a mediating variable of Industry 4.0 and organizational performance have not yet been observed.

With the theoretical framework analyzed, the following research hypotheses were proposed. The theoretical model is presented in Figure 1.

H1. There is a positive relationship between Industry 4.0 and the organizational performance of medium and large companies in Ecuador, Colombia, and Peru.

H2. There is a positive relationship between medium and large companies 'social culture and organizational performance in Ecuador, Colombia, and Peru.

H3. Social culture mediates the relationship between Industry 4.0 technologies and organizational performance in medium and large companies in Ecuador, Colombia, and Peru.

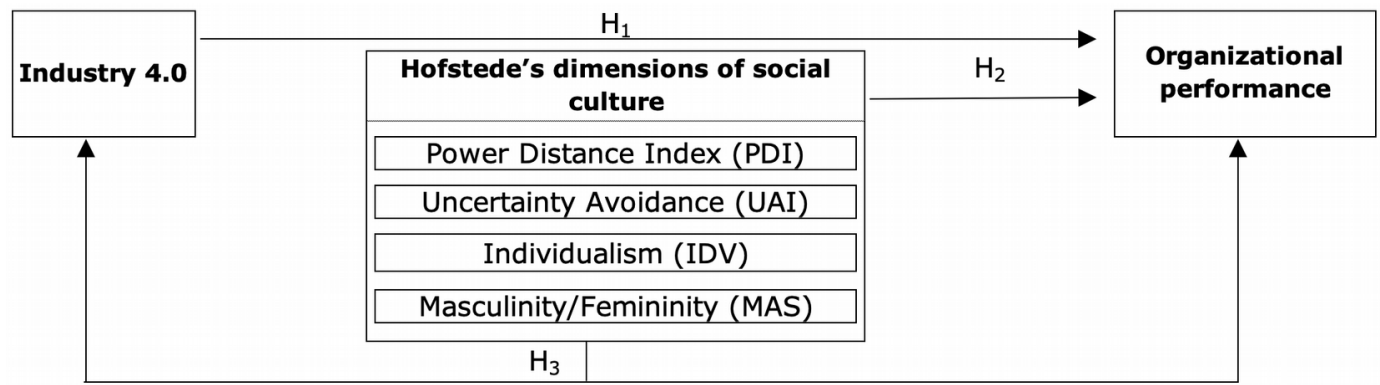

Figure 1. Proposed Research Model. Model between Industry 4.0, social culture, and organizational performance

\section{Research Methodology}

The data was collected through online surveys of workers in large and medium-sized companies in Ecuador, Colombia, and Peru. Through data processing in SPSS (IBM, 2020) and Amos developed a Structural Equation Model (SEM).

\subsection{Population and Sample}

The population was made up of employees of medium and large companies in Ecuador, Colombia, and Peru, according to the classification of companies by size for Latin America (World Bank Group, 2014, 2020), which considers: (1) medium-sized companies, more than 50 workers; and (2) large companies, more than 200 employees. These companies were also part of the SE database, which orders them by size, legal status, property characteristics, saleable condition, and informal or unregistered links (World Bank Group, 2014, 2020). The companies participating in the study belong to a variety of sectors of economic activity, have a minimum of five years of training, are a national and foreign investment, and are from the capital cities of the three countries. This proposal is to have a broad vision of medium and large companies in those countries.

The choice of companies in these countries is because these countries belong to emerging economies: (1) Ecuador is in the first phase of growth; and (2) Colombia and Peru are more advanced economies, which as a whole are considered representative of Latin America and have similar organizational structures, as well as similarities in the 
cultural dimensions of their inhabitants (Hofstede Centre, 2021). Furthermore, LAC ranks third among the world's largest economies, in which its inhabitants relate by historical, cultural, and economic ties (ECLAC, 2020b, 2020a).

700 employees from the same number of medium and large companies were invited. They conducted an online survey through the Microsoft Forms platform from May to November 2020. Were conducted no personal surveys because the Covid 19 Pandemic confinement forced all workers to carry out their activities from home. Respondents signed an informed consent in which the parameters of the research were detailed. They have been told that the information collected would be treated globally, confidentially, and anonymously. Through data quality controls during the questionnaire administration, obtained a sample of 527 workers; only 428 surveys were considered valid.

\subsection{Instrumentation}

A survey was designed, composed of demographic, geographic, and multiple-choice questions. In addition, the main constructs: (1) Social Culture (CS) were constructed items from the cultural dimensions proposed by Hofstede (Beugelsdijk, Kostova, Kunst, Spadafora \& van Essen, 2018); (2) Industry 4.0 (IT) technologies with items built from the literature review described above, and this the same for (3) Organizational Performance (OP). The items were structured on a five-point Likert scale: 1 for totally disagree and 5 for totally agree (Byrne, 2010). The final list of elements is presented in Table 1.

\begin{tabular}{|c|c|c|c|}
\hline Constructs & Items & Label & Related literature \\
\hline $\begin{array}{l}\text { Demographic and } \\
\text { geographic } \\
\text { information }\end{array}$ & Country, city, company name, tenure, sector, and economic activity. & & Nominal scale \\
\hline \multirow[t]{19}{*}{ Social culture (SC) } & $\begin{array}{l}\text { There are some jobs in which a man can always do better than a } \\
\text { female. }\end{array}$ & MAS1 & \multirow{19}{*}{$\begin{array}{l}\text { Gallivan \& Srite, } \\
\text { 2005; Srite, 2006; } \\
\text { Tarhini et al., 2015, } \\
2017\end{array}$} \\
\hline & There should be a male in a senior position rather than a female. & MAS2 & \\
\hline & $\begin{array}{l}\text { It is more important for a male than for female to have a professional } \\
\text { career. }\end{array}$ & MAS3 & \\
\hline & Female do not value professional achievement as much as male do. & MAS4 & \\
\hline & $\begin{array}{l}\text { Usually, male solve problems with logical analysis, while female do so } \\
\text { with intuition. }\end{array}$ & MAS5 & \\
\hline & $\begin{array}{l}\text { Males are more determined and competitive, focusing on } \\
\text { achievement and material success, while female are humbler, focusing } \\
\text { on relationships and quality of life. }\end{array}$ & MAS6 & \\
\hline & Workers should sacrifice self-interest for the group that they belong to. & IDV1 & \\
\hline & Workers should stick with the group even through difficulties. & IDV2 & \\
\hline & Group welfare is more important than individual rewards. & IDV3 & \\
\hline & Group success is more important than individual success. & IDV4 & \\
\hline & Group loyalty should be encouraged even if individual goals suffer. & IDV5 & \\
\hline & $\begin{array}{l}\text { Being accepted as a member of a group is more important than } \\
\text { having autonomy and independence. }\end{array}$ & IDV6 & \\
\hline & Workers should not question their manager's decisions. & PDI1 & \\
\hline & Superiors should not ask the opinions of workers too frequently. & PDI2 & \\
\hline & Superiors should avoid social interaction with workers. & PDI3 & \\
\hline & $\begin{array}{l}\text { It is frequently necessary for superiors to use authority and power } \\
\text { when dealing with workers. }\end{array}$ & PDI4 & \\
\hline & Superiors should not delegate important tasks to workers. & PDI5 & \\
\hline & Superiors should make most decisions without consulting workers. & PDI6 & \\
\hline & Rules and regulations are important because they inform workers & UAI1 & \\
\hline
\end{tabular}




\begin{tabular}{|c|c|c|c|}
\hline Constructs & Items & Label & Related literature \\
\hline & what the company expects of them. & & \\
\hline & $\begin{array}{l}\text { It is important to have specific rules and instructions so that workers } \\
\text { always know what they are expected to do. }\end{array}$ & UAI2 & \\
\hline & $\begin{array}{l}\text { It is important to closely follow instructions and procedures related } \\
\text { to worker training. }\end{array}$ & UAI3 & \\
\hline & Standardized work procedures are helpful for your learning. & UAI4 & \\
\hline & Instructions for operations are important to your learning. & UAI5 & \\
\hline \multirow{11}{*}{$\begin{array}{l}\text { Industry } 4.0 \\
\text { technologies (IT) }\end{array}$} & Automation of processes. & IT1 & \multirow{11}{*}{$\begin{array}{l}\text { Huang et al., 2019; } \\
\text { Kamble et al., } 2020\end{array}$} \\
\hline & Cloud computing services. & IT2 & \\
\hline & Analytics (big data). & IT3 & \\
\hline & $\begin{array}{l}\text { Digital services in products ("Internet of things" or Product Service } \\
\text { Systems). }\end{array}$ & IT4 & \\
\hline & Additive manufacturing systems, rapid prototyping, or 3D printing. & IT5 & \\
\hline & Collaborative robotics. & IT6 & \\
\hline & Remote control technologies (Drones). & IT7 & \\
\hline & Production systems based on augmented reality. & IT8 & \\
\hline & Use of Blockchain & IT9 & \\
\hline & Geolocation systems. & IT10 & \\
\hline & Cybersecurity systems. & IT11 & \\
\hline \multirow{21}{*}{$\begin{array}{l}\text { Organizational } \\
\text { performance }(\mathrm{OP})\end{array}$} & They changed or improved production processes. & OP1 & \multirow{21}{*}{$\begin{array}{l}\text { Gawankar et al., } \\
\text { 2020; Gupta \& } \\
\text { George, } 2016\end{array}$} \\
\hline & $\begin{array}{l}\text { New products or services were created, or existing ones were } \\
\text { significantly improved. }\end{array}$ & OP2 & \\
\hline & The way of managing the company was changed or improved. & OP3 & \\
\hline & The company's relations with the community improved. & OP4 & \\
\hline & The company's relations with state entities improved. & OP5 & \\
\hline & The company adapted to international standards. & OP6 & \\
\hline & Improved customer relationships. & OP7 & \\
\hline & Improved relationships with suppliers. & OP8 & \\
\hline & Improved market positioning. & OP9 & \\
\hline & New markets (national and international) were accessed. & OP10 & \\
\hline & Waste levels were reduced. & OP11 & \\
\hline & Refunds due to non-conformity decreased. & OP12 & \\
\hline & More and better job opportunities were created. & OP13 & \\
\hline & Policies for labor flexibility were improved. & OP14 & \\
\hline & Work accidents will be reduced. & OP15 & \\
\hline & Improved working conditions (work environment and wages). & OP16 & \\
\hline & Staff were trained in job skills and human development. & OP17 & \\
\hline & Sales increased. & OP18 & \\
\hline & Income increased. & OP19 & \\
\hline & Company profits increased. & OP20 & \\
\hline & Investments were made for business growth. & OP21 & \\
\hline
\end{tabular}

Table 1. Scale items for constructs 
Descriptive statistics for the sample composition are shown in Table 2. 44\% correspond to medium-sized companies and 56\% to large companies. Also, 92\% belong to private companies and only $8 \%$ to public companies, considering a more excellent participation manufacturing and industrial sectors of at least $46 \%$.

\section{Data Analysis and Results}

\subsection{Reliability and Validity}

The Kaiser Meyer Olkin Index (KMO) suggests values above 0.8 (Byrne, 2010; Hair, Black, Babin \& Anderson, 2010; Hoyle, 2015) it was 0.936 for the SC dimension, 0.917 for IT, and 0.973 for OP. Cronbach's alpha coefficient was 0.97, above the recommended level of 0.6 (Hair et al., 2010; Powell, 1992).

\subsection{Exploratory and Confirmatory Factor Analysis}

The Exploratory Factor Analysis (EFA) suggested deleting 11 SC items (P7, P8, P9, P10, P11, P19, P20, P21, P22, and P23) and five IT items (P24, P25, P26, P27, and P34). Confirmatory Factor Analysis (CFA), to define the degree of statistical plausibility and the level of adjustment of the hypotheses of the model (Hoyle, 2015; Raykov \& Marcoulides, 2006), used the Chi-Square or CMIN test (minimum discrepancy). CMIN/DF (Byrne, 2010) y RMSEA (Root mean square error of approximation) were indicators to explain how well the model adjusted to the population covariance matrix, indicating the mean residual correlation, which should have been less than 0.080 to be accepted and less than 0.050 to identify a perfect fit. (Hoyle, 2015). The indexes RFI (Relative-of-fit index), NFI (Normative-of-fit index), TLI (Tucker-Lewis index), GFI (Goodness-of-fit index) determined the level of adjustment of variance and covariance of the matrices, regardless of sample size (Raykov \& Marcoulides, 2006) and CFI (Comparative fit index), confirmed that the model hypotheses were adequate with the sample data. The last two indicators have a minimum recommended level of 0.90 (Hoyle, 2015).

\begin{tabular}{|c|c|c|c|c|c|c|c|c|c|c|}
\hline \multirow{2}{*}{$\begin{array}{l}\text { Economy } \\
\text { activity }\end{array}$} & \multirow{2}{*}{$\begin{array}{l}\text { Company } \\
\text { sector }\end{array}$} & \multirow{2}{*}{ Country } & \multicolumn{5}{|c|}{ Range \# workers } & \multirow{2}{*}{\multicolumn{3}{|c|}{ Total }} \\
\hline & & & $50-100$ & 101-151 & $152-202$ & $203-253$ & $254-700.000$ & & & \\
\hline \multirow{5}{*}{ CMM } & \multirow{3}{*}{ Private } & Ecuador & 3 & 1 & 1 & 0 & 0 & 5 & & \\
\hline & & Peru & 0 & 0 & 0 & 0 & 10 & 10 & & \\
\hline & & Colombia & 7 & 2 & 2 & 1 & 40 & 52 & 67 & \\
\hline & \multirow{2}{*}{ Public } & Ecuador & & & & & 3 & 3 & & \\
\hline & & Peru & & & & & 2 & 2 & 5 & $17 \%$ \\
\hline \multirow{4}{*}{ SRV } & \multirow{3}{*}{ Private } & Ecuador & 6 & 1 & 7 & 1 & 10 & 25 & & \\
\hline & & Peru & 1 & 1 & 2 & 0 & 31 & 35 & & \\
\hline & & Colombia & 55 & 6 & 5 & 3 & 28 & 97 & 157 & \\
\hline & Public & Colombia & & & & & 1 & 1 & 1 & $37 \%$ \\
\hline \multirow{5}{*}{ MND } & \multirow{3}{*}{ Private } & Ecuador & 5 & 5 & 2 & 1 & 21 & 34 & & \\
\hline & & Peru & 2 & 6 & 6 & 0 & 47 & 61 & & \\
\hline & & Colombia & 38 & 7 & 3 & 1 & 25 & 74 & 169 & \\
\hline & \multirow{2}{*}{ Public } & Ecuador & 2 & & 2 & 1 & 14 & 19 & & \\
\hline & & Colombia & 1 & & 0 & 0 & 9 & 10 & 29 & $46 \%$ \\
\hline \multirow{2}{*}{\multicolumn{3}{|c|}{ Total }} & 120 & 29 & 30 & 8 & 241 & 428 & $92 \%$ & \\
\hline & & & $28 \%$ & $7 \%$ & $7 \%$ & $2 \%$ & $56 \%$ & $100 \%$ & $8 \%$ & \\
\hline
\end{tabular}

CMM: Commercialization; SRV: Services; MND: Manufacturing/Industry

Table 2. Summary of descriptive statistics of the sample 
Table 3 presents the results of the CFA. For SC, evidenced compliance with the CMIN / DF, RMSEA, TLI, NFI, RFI, II, and CFI indices with loads between 0.59 and 0.93 for each of the six resulting indicators considered positive values the model. For IT, a good fit was obtained with the TLI, NFI, RFI, IFI, CFI indices, but not as adequate with the CMIN / DF, RMSEA indicators. For OP, the indices of CMIN/DF, RMSEA, TLI, NFI, RFI, IFI, and CFI were appropriate to explain the model. Thus, the variable OP is identified as a very consistent variable in its indicators.

\begin{tabular}{|c|c|c|c|c|c|c|c|c|c|}
\hline Iterations & CMIN & CMIN/DF & RMSEA & NFI & RFI & IFI & TLI & CFI & No. Ind \\
\hline \multicolumn{10}{|l|}{ SC } \\
\hline Initial & 645.829 & 9.785 & .143 & .864 & .840 & .876 & .854 & .876 & 13 \\
\hline Final & 17.09 & 1.899 & .046 & .992 & .986 & .996 & .994 & .996 & 6 \\
\hline \multicolumn{10}{|l|}{ IT } \\
\hline Initial & 140.831 & 15.648 & .185 & .922 & .870 & .926 & .877 & .926 & 6 \\
\hline Final & 16.565 & 8.283 & .131 & .983 & .949 & .985 & .955 & .985 & 4 \\
\hline \multicolumn{10}{|l|}{ OP } \\
\hline Initial & 1716.4 & 9.081 & .138 & .853 & .836 & .867 & .862 & .867 & 21 \\
\hline Final & 24.538 & 1.753 & .042 & .991 & .987 & .996 & .994 & .996 & 7 \\
\hline
\end{tabular}

Table 3. Fit indices and non-standardized coefficients for the iterations of the CFA for the dimensions of SC, IT, and OP

The data in Table 4 show that, due to the CFA, six SC items were significant with impact values greater than $0.59,4$ IT indicators had values greater than 0.65 , and seven OP items were more outstanding than 0.50 .

\begin{tabular}{|c|c|c|c|c|c|}
\hline Social culture & Impact & Industry 4.0 technologies & Impact & Organizational performance & Impact \\
\hline MAS1 & & IT5 & & OP1 & \\
\hline MAS2 & 0.89 & IT6 & 0.79 & $\mathrm{PO} 2$ & \\
\hline MAS3 & 0.91 & IT7 & 0.91 & OP3 & 0.86 \\
\hline MAS4 & 0.93 & IT8 & 0.87 & OP4 & \\
\hline MAS5 & 0.89 & IT9 & & OP5 & 0.81 \\
\hline MAS6 & & IT10 & 0.62 & OP6 & 0.87 \\
\hline IDV6 & 0.59 & & & OP7 & 0.90 \\
\hline PDI1 & & & & OP8 & 0.90 \\
\hline PDI2 & & & & OP9 & \\
\hline PDI3 & 0.71 & & & OP10 & 0.91 \\
\hline PDI4 & & & & OP11 & \\
\hline PDI5 & & & & OP12 & \\
\hline \multirow[t]{9}{*}{ PDI6 } & & & & OP13 & 0.80 \\
\hline & & & & OP14 & \\
\hline & & & & OP15 & \\
\hline & & & & OP16 & \\
\hline & & & & OP17 & \\
\hline & & & & OP18 & \\
\hline & & & & OP19 & \\
\hline & & & & OP20 & \\
\hline & & & & OP21 & \\
\hline
\end{tabular}

Table 4. Fit indices and non-standardized coefficients for the iterations of the CFA for the dimensions of SC, IT, and OP 


\subsection{Structural Equations Model for the Relationship Between Social Culture and Technologies 4.0 with Organizational Performance}

Following the previous results and using the Structural Equations Model (SEM), we proceeded to respond to the research hypotheses. The initial structural model was developed to verify $\mathrm{H} 1$ and $\mathrm{H} 2$. After two iterations between IT and OP and SC and OP, eliminated two items for the first relationship and one item for the second relationship. While for SC as a mediating variable between IT and OP, one item was deleted. Table 5 shows that the model reaches adequate levels of adjustment.

Figure 2 shows that there is a direct and positive relationship between IT and OP (H1). However, SC is not a mediating variable $(-0.23)$ of the relationship between the use of IT and OP (H3); besides, there is no positive relationship between SC and $\mathrm{OP}(\mathrm{H} 2)$.

\begin{tabular}{|c|c|c|c|c|c|c|c|c|c|}
\hline Iterations & CMIN & CMIN/DF & RMSEA & NFI & RFI & IFI & TLI & CFI & No. Ind \\
\hline \multicolumn{10}{|c|}{ IT-OP (Second order) } \\
\hline Initial & 156,042 & 3.546 & .077 & .961 & .951 & .9721 & .964 & .972 & 11 \\
\hline Final & 41.311 & 1.589 & .037 & .987 & .983 & .995 & .994 & .995 & 9 \\
\hline \multicolumn{10}{|c|}{ SC-OP (Second order) } \\
\hline Initial & 231,396 & 3.560 & .077 & .954 & .945 & .966 & .960 & .966 & 13 \\
\hline Final & 89.535 & 1.689 & .040 & .981 & .977 & .992 & .990 & .992 & 12 \\
\hline \multicolumn{10}{|l|}{ IT-SC-OP } \\
\hline Initial & 256,368 & 2.191 & .053 & .960 & .953 & .978 & .974 & .978 & 17 \\
\hline Final & 168.530 & 1.669 & .040 & .972 & .967 & .989 & .987 & .989 & 16 \\
\hline
\end{tabular}

Table 5. Fit indices, for the iterations of the structural model for the dimensions of IT-OP, SC-OP, and IT-OP mediated by SC

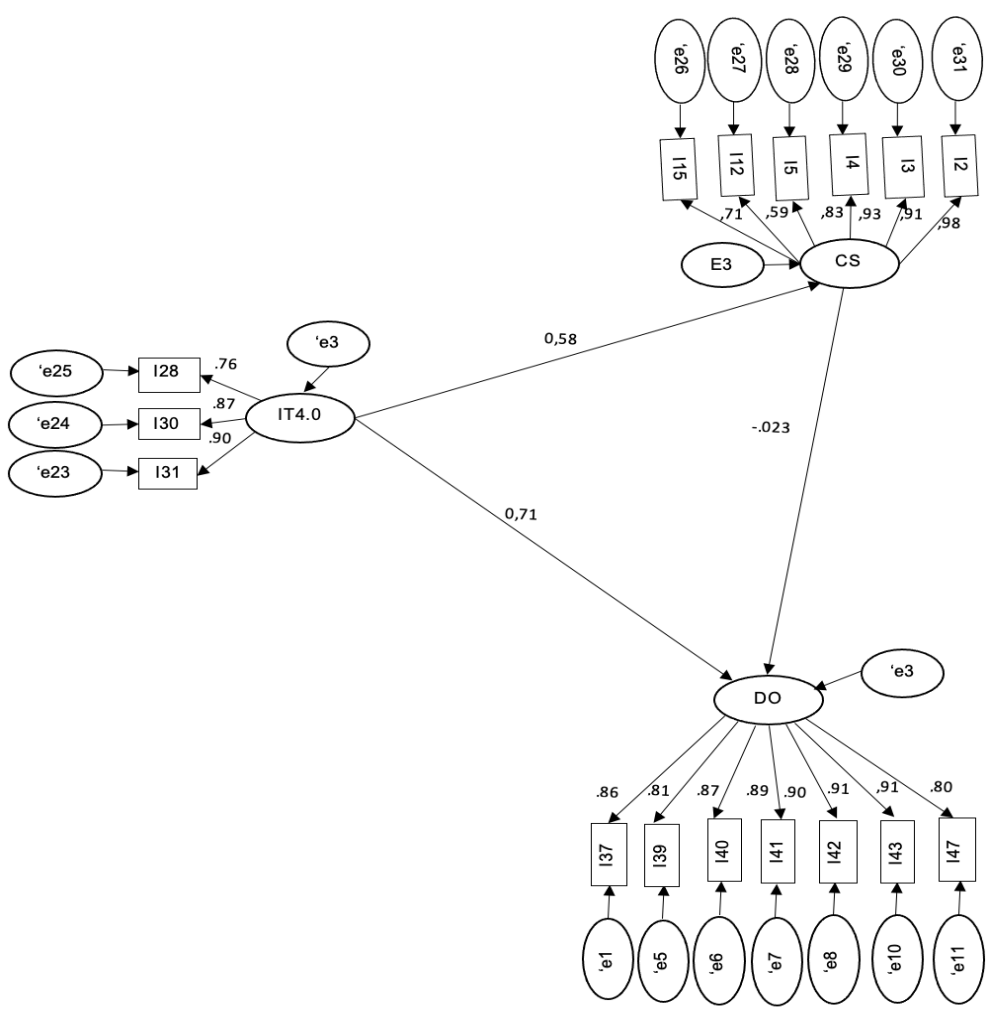

Figure 2. SEM of the relationship between Industry 4.0 technologies and organizational performance mediated by social culture 
On the other hand, an analysis of the companies' data by country, as evidenced in Table 6 , shows that their results are varied for the relationship between SC and OP. While for companies in Peru, this relationship is highly significant with a high impact (0.81), for companies in Colombia and Ecuador, it is moderately impactful (0.39 and 0.32 respectively). Also, the relationship between IT and OP variables was different. Although for companies in Colombia (0.45) and Ecuador (0.33), this relationship has a medium impact, for companies in Peru (0.89), it is highly relevant, even though these variables require a more significant adjustment for Peru of the structural model.

\begin{tabular}{|l|r|l|r|}
\hline \multicolumn{1}{|c|}{ Relations } & \multicolumn{1}{c|}{ Estimate } & \multicolumn{1}{c|}{ Relations } & \multicolumn{2}{c|}{ Estimate } \\
\hline OP $<---$ SC Ecuador & .32 & OP <--- IT Ecuador & .33 \\
\hline OP <--- SC Colombia & .39 & OP <--- IT Colombia & .45 \\
\hline OP <--- SC Peru & .81 & OP <--- IT Peru & .89 \\
\hline
\end{tabular}

Table 6. Standardized coefficients

\section{Discussion}

The findings of the study show a relationship between the technologies of Industry 4.0 and social culture with the dimensions MAS (with a predominance of masculinity), IDV (with a predominance of collectivism), and PDI (with a high-power distance), which impact in organizational performance. A high degree of masculinity shows that employees value achievement, recognition, promotion, and professional competence, focused on their success and actions related to tasks (Minkov \& Hofstede, 2011). However, a high power distance makes them fear to disagree with superiors who adopt an autocratic or paternalistic style (Hofstede, 2013). Also, a low index of individualism promotes loyalty before any social norm (Hofstede, Hofstede \& Minkov, 2010), orienting them to a group mentality and taking responsibility for each group member.

With high MAS, IDV, and PDI characteristics in the analysis countries (Hofstede Centre, 2021), This research confirms that national cultures influence companies' performance. As proposed by the Hofstede framework, when it establishes that national cultures are reflected in an organization's employees (Hofstede, 1983, 2001a; Hofstede et al., 2010). Therefore, by combining masculinity with power distance and collectivism, employees could achieve better levels of motivation and work excellence; Because, although they value hierarchical levels, they also appreciate the recognition and belonging to the group, which would generate commitment among their subordinates and directors, as well as among the activities they carry out in the organization.

Also found that some performance indicators evaluated in the study, such as (1) improving relationships between providers, (2) improve customer relationships, (3) improve relations with State entities; (4) access to new markets, (5) adaptability to international standards, (6) changes or improvements in administration, and (7) the creation of more and better job opportunities, derived from values, routines and distinctive aspects of social culture, mainly focused on the dimensions of MAS, IDV, and PDI. These results are in line with those of research carried out by Saad and Abbas (2018) and Vrânceanu and Iorgulescu (2016), who affirm that the features of social culture contribute to generating competitive advantage and, therefore, have effects on organizational performance.

On the other hand, it is suggested that technology defines cultural values and social structure in companies. In this sense, the use of (1) remote control technologies, (2) production systems based on augmented reality, (3) collaborative robotics, and (4) geolocation systems. Also, it is found that Industry 4.0 in medium and large companies impacts their performance and is not considered an organizational disadvantage when replacing the intellectual capital of workers. These because other research affirms that industrialization contributes to the degradation of the workforce (Acemoglu, 2002; Atasoy, 2012; Luthra \& Mangla, 2018). This research confirms that the adoption of Industry 4.0 positively impacts the well-being of the companies.

Companies should consider using 4.0 technologies in possible government collaboration (new initiatives and improvements in sustainability and growth), even more so when one of the relevant performance indicators in this study corresponded to "improving the company's relationships with entities of the State". Besides, organizations' 
culture encourages creativity and supports innovation (Barczyk et al., 2019; Cheung et al., 2012; Huang et al., 2019; Srisathan et al., 2020).

Industry 4.0 technologies, therefore, contribute to digital transformation. Some examples have been finding in the manufacturing (Das \& Dey, 2021; Sophie et al., 2020) and energy (Borowski, 2021) sectors, but they have been more evident in the automotive and service industries (Demeter et al., 2020; Ghobakhloo, 2018). Although they have been developing in industrialized nations, this study, which covers many large and medium-sized companies from various sectors of economic activity, also demonstrates their effectiveness in emerging economies.

Also found significant differences for each country between social culture and organizational performance and between Industry 4.0 technologies and the firm's performance. For Peru, this relationship is more critical than for Colombia and Ecuador. These results could show two situations: (1) the practices of social culture and technologies are different in each country, or (2) that the language used in each of them may be different. To this, Peru has probably had better results from the implementation of Industry 4.0 in its companies. For example, Hochschild and Buenaventura have incorporated innovation leaders into their teams. The Io'T and autonomous machines' significant adaptability is observed in urban areas, making the mining industry a key market in this country (Global Business Reports, 2019). Also, although Ecuador is ranked 99 (24.11\%), Colombia 68 (30.84\%), and Peru 76 (28.79) on the Global Innovation Index (World Intellectual Property Organization, 2020), the latter is one of the fastest-growing countries in the region (Global Entrepreneurship Monitor, 2019; World Economic Forum, 2019). It has with 5.2\% per year of GDP between 2000-2016 (McKinsey Global Institute, 2019) and has recent innovation programs that are making enterprises in various productive sectors the base of companies with a high level of 4.0 technologies (Ministerio de la Producción, 2021).

On the other hand, because global companies have high failure rates due to difficulties in managing mixed cultural teams (individual behaviour patterns and distinctive organizational styles converge for different nations), this study emphasizes that Industry 4.0 and social culture are conclusive in the way in which a digital transition is carried out. So organizations must address a change in their culture that allows them to adopt these technologies in their structures and processes. Ziaei Nafchi and Mohelská (2020), For example, found that to implement Industry 4.0, the culture adopted does not depend on the size but the organization type. However, the company's size is a decisive factor to compete in foreign markets (Beausang, 2003; Martí, Alguacil \& Orts, 2017; Moon \& Lee, 2004; Rugman, Oh \& Lim, 2012). Several functions previously performed by corporate headquarters have been decentralized and are often performed in emerging economies (Luo, Zhang \& Bu, 2019). In Industry 4.0, it is important to contemplate the cultural differences between the countries' economies.

In this way, those who run companies must know their workers' social culture to determine whether a technology will be accepted and develop strategies that overcome their cultural resistance. Market demands demand greater competitiveness, being necessary to analyze the effect of this problem with industrial automation by applying new technologies, proposing different organizational challenges, changing the way of doing business, and optimizing the job. Thus, managers of medium and large companies in the emerging economies must take advantage of the cultural differences shown in the personality traits of employees to achieve acceptance of Industry 4.0 technologies and emphasize that these compromises the future of intellectual capital in organizational performance even more so when (1) remote control technologies and (2) production systems based on augmented reality were more significant in the study.

Therefore, this research expands on previous findings (for example, Roy, 2020; Usoro and Abiagam, 2018) and motivates organizations in emerging economies to emphasize (1) masculinity to make knowledge explicit in computer and technological systems, (2) collectivism, which encourages and facilitates knowledge exchange and collaborative work, which often today it is done virtually; and (3) the power distance in which the hierarchical and departmental levels promote the updating of knowledge in the workers and guarantee the promotion, which besides, with learning in the workplace, would generate agility and competitiveness (Singh et al., 2016). Thus, it is relevant to take such actions, even more so when only Latin America projects a masculinity rate by 2050 of $106.8 \%$ (CELADE et al., 2019). 
Contrary to expectations, a mediating effect by social culture has not been identified in the relationship between Industry 4.0 technologies and organizational performance. This makes it possible to know that even in a culturally diverse environment, a company performance can increase with adopting the respective technological pillars, allowing organizations a recruitment system focused on competencies and not on cultural values. Therefore, the idea arises that an organization work environment is not subject to homogeneity cultural in the members of the work team or is even losing association with job performance.

\section{Conclusions}

This study examines the effects of Industry 4.0 technologies, social culture, and organizational performance of medium and large companies in Ecuador, Colombia, and Peru. Together with the enrichment of the existing literature, the results broaden the understanding of medium and large companies in emerging economies and confirm that the different technological advances can bring other implications for firms' performance because it defines cultural values and the social structure.

Found that Industry 4.0 technologies were positively related to organizational performance and a negative relationship between social culture and firms' performance. Furthermore, that social culture did not mediate between Industry 4.0 and organizational performance. These findings invite us to take advantage of the digital transformation and incorporate policies to promote technology development. With automation and globalization, it is not enough to apply traditional methods of process optimization. Still, new approaches are needed, subject to market needs, which require greater competitiveness and improvement of work. Likewise, national cultures may likely be skewing the company's efforts. It is a priority to combine the firms' best performance with the organizational culture, forcing organizations to encourage investment in new technological pillars. Especially in emerging countries requires an upgrade in connectivity to reduce the competitive gap in the productive sector and a more significant comparative advantage with developed countries.

On the other hand, as the study's predominant dimensions were MAS, PDI, and IDV, they generate variations in values and social differences, which drive many different cultural factors. A combination of these dimensions shows that the workers of companies in emerging economies easily accept an unequal distribution of power but appreciate the dominance of aggressiveness, achievement, and acquisition of material wealth, the results of which are reflected in group achievements. However, depending on the type and industrial sector, we must carefully analyze social culture.

Finally, the level of maturity of medium and large companies in emerging economies is still developing, which indicates a potential to increase and improve their productivity after the application of Industry 4.0. As this is not considered an organizational disadvantage, training is needed at all levels and $\mathrm{R}+\mathrm{D}+\mathrm{i}$ activities that lead to innovation in process management and the market's expansion in the local and international context.

\section{Implications, Limitations and Suggestions for Future Research of the Study 7.1. Implications}

This study has relevant theoretical and practical implications. The current literature does not address similar studies that jointly analyze Industry 4.0, social culture, and organizational performance, especially in emerging economies such as Ecuador, Colombia, and Peru. For this reason, this analysis provides, to the academics and professionals of the administrative-economic field, a frame of reference that broadens the research in this area, mainly because knowing the cultural differences of the workers of the medium and large companies will help the policyholders' decision-makers design international benefits programs that, as part of organizational performance, will improve and increase the participation and positioning of their markets.

Furthermore, this study emphasizes three dimensions of Hofstede in intercultural management: MAS, PDI, and IDV. Therefore, it will be necessary for companies to consider, among other things, assessing (1) salary differences, (2) the classification of hierarchical levels, (3) membership in work teams as drivers of organizational performance, and (4) the association of social culture and generational change. The mix of these dimensions may prioritize the use of Industry 4.0 technologies, which will limit to (1) remote control technologies, (2) production systems based on augmented reality, (3) collaborative robotics, and (4) geolocation systems. Finally, the results of this study 
suggest that Industry 4.0 technologies promote the best performance of organizations. At the same time, they are necessary to form employees' social culture, without prejudice to the displacement of intellectual capital or operational. Thus, it is evident that it will reflect its employees' culture because the national culture is more dominant due to its cultural impact.

\subsection{Limitations}

Although the study provides findings that contribute to the context of emerging economies and the existing literature, it has particular limitations that must take with care: (1) although the sample was representative and met the statistical criteria of reliability and validity, the same number of surveys for Ecuador, Colombia, and Peru, which could assume a certain bias of sample representativeness towards one of the three countries, (2) the study included various sectors and economic activities of medium and large companies, the results of which could have been concentrated in one type of industry, and (3) workers' responses, in some cases, could be affected by personal biases and skew the research results. This does not detract from the study's usefulness; it provides a basis for future research in other markets and broadens the possibility of generalizing the findings by replicating the study and expanding the areas of interest covered in this research.

\subsection{Future Research}

As this is the first study related to Industry 4.0, social culture, and organizational performance, (1) new research is needed, including other LAC populations and helps to enlarge the results found. Also, it will be necessary (2) to incorporate a detailed analysis by industry, type, and sector, with another company classification (for example, annual turnover and contribution to GDP), validated by longitudinal designs, to systematize the effects presented here. Also, (3) future research is required to measure the social culture and organizational culture in the performance of firms to identify better which of them is more influential in companies in emerging economies, even more so when the literature addresses differences in these findings (4) consider that generational changes have transformed cultural values and therefore, job performance has changed from the perspective of human talent. Also, although this study values Hofstede's cultural dimensions for their high impact on international business research, (5) other studies could combine these dimensions with the GLOBE and WVS framework and evaluate cultural changes when there are multinational organizations within workers of different nationalities, regions, generations, and socioeconomic groups. It is necessary to evaluate the effectiveness of traditional human management practices such as a work environment study. Without the mediation of social culture in organizational performance, people's account is associated with the tools they have to carry out their work, not peer relationships. Finally, (6), in addition to evaluating organizational culture and performance, includes other measurements such as job satisfaction and performance, mainly considering the environment's changes due to the outbreak of the Covid-19 pandemic.

\section{Declaration of Conflicting Interests}

The authors declared no potential conflicts of interest with respect to the research, authorship, and/or publication of this article.

\section{Funding}

The authors received financial support for the publication of this article by Universidad de Las Américas-Ecuador.

\section{References}

Acemoglu, D. (2002). Technical change, inequality, and the labor market. Journal of Economic Literature, 40(1), 7-72. https://doi.org/10.3386/w7800

Atasoy, H. (2012). The effects of broadband internet expansion on labor market outcomes. SSRN Electronic Journal, 66(2). https://doi.org/10.2139/ssrn.1890709

Atasoy, H. (2013). The effects of broadband internet expansion on labor market outcomes. SSRN Electronic Journal, 66(2), 314-245. https://doi.org/10.2139/ssrn.1890709 
Barczyk, C.C., Rarich, C.A., Klonowsky, M., \& Angriawan, A. (2019). Structuring organizational culture to complement Poland's national culture - An approach for achieving high impact entrepreneurship. The Journal of Applied Business and Economics, 21(2), 11-26.

Baumgartner, H., \& Weijters, B. (2017). Methodological issues in cross-cultural research. In Cross Cultural Issues in Consumer Science and Consumer Psychology: Current Perspectives and Future Directions (169-190). https://doi.org/10.1007/978-3-319-65091-3

Beausang, F. (2003). Competitiveness of multinational enterprises. In Third World Multinationals (62-77). Palgrave Macmillan. https://doi.org/10.1057/9780230508323_4

Beugelsdijk, S., Kostova, T., Kunst, V.E., Spadafora, E., \& van Essen, M. (2018). Cultural distance and firm internationalization: A meta-analytical review and theoretical implications. Journal of Management, 44(1), 89-130. https://doi.org/10.1177/0149206317729027

Beugelsdijk, S., \& Welzel, C. (2018). Dimensions and dynamics of national culture: Synthesizing Hofstede with Inglehart. Journal of Cross-Cultural Psychology, 1-37. https://doi.org/10.1177/0022022118798505

Bizanis, N., \& Kuipers, F.A. (2016). SDN and virtualization solutions for the Internet of Things: A survey. IEEE Access, 4, 5591-5606. https://doi.org/10.1109/ACCESS.2016.2607786

Borowski, P.F. (2021). Digitization, digital twins, blockchain, and Industry 4.0 as elements of management process in enterprises in the energy sector. Energies, 14(7), 1-21. https://doi.org/10.3390/en14071885

Brettel, M., Friederichsen, N., Keller, M., \& Rosenberg, M. (2014). How virtualization, decentralization and network building change the manufacturing landscape: An Industry 4.0 perspective. International Journal of Information and Communication Engineering, 8(1), 37-44.

Byrne, B.M. (2010). Structural equation modeling with AMOS: Basic concepts, applications, and programming. Routledge. Taylor and Francis Group. https://doi.org/10.4324/9781410600219

Carballo, M., \& Moreno, A. (2013). Changing values in Latin America.

CELADE, Population Division of ECLAC, Revision and United Nations, \& Department of Economic and Social Affairs. (2019). CEL ADE. Latin America and the Caribbean: Population Estimates and Projections. https://population.un.org/wpp/

Cheung, S.O., Wong, P.S.P., \& Lam, A.L. (2012). An investigation of the relationship between organizational culture and the performance of construction organizations. Journal of Business Economics and Management, 13(4), 688-704. https://doi.org/10.3846/16111699.2011.620157

Coldwell, D.A.L. (2019). Negative influences of the 4th industrial revolution on the workplace: Towards a theoretical model of entropic citizen behavior in toxic organizations. International Journal of Environmental Research and Public Health, 16(15), 2670. https://doi.org/10.3390/ijerph16152670

Dalenogare, L.S., Benitez, G.B., Ayala, N.F., \& Frank, A.G. (2018). The expected contribution of Industry 4.0 technologies for industrial performance. International Journal of Production Economics, 204, 383-394. https://doi.org/10.1016/j.ijpe.2018.08.019

Das, A., \& Dey, S. (2021). Global manufacturing value networks: assessing the critical roles of platform ecosystems and Industry 4.0. Journal of Manufacturing Technology Management. https:/ / doi.org/10.1108/JMTM-04-2020-0161

Dash, K., Mohapatra, D., Das, M.R., \& Sahoo, R. (2018). Smart manufacturing \& future prospects on logistics. International Research Journal of Engineering and Technology, 5(11), 1798-1801.

Dassisti, M., Giovannini, A., Merla, P., Chimienti, M., \& Panetto, H. (2019). An approach to support Industry 4.0 adoption in SMEs using a core-metamodel. Annual Reviews in Control, 47, 266-274.

https://doi.org/10.1016/j.arcontrol.2018.11.001

Dastmalchian, A., Bacon, N., McNeil, N., Steinke, C., Blyton, P., Satish Kumar, M. et al. (2020). High-performance work systems and organizational performance across societal cultures. Journal of International Business Studies, 51(3), 353-388. https://doi.org/10.1057/s41267-019-00295-9 
Demeter, K., Losonci, D., Marciniak, R., Nagy, J., Móricz, P., Matyusz, Z. et al. (2020). Industry 4.0 through the lenses of technology, strategy, and organization: A compilation of case study evidence. Vezetéstudomány / Budapest Management Review, 51(11), 14-25. https:// doi.org/10.14267/veztud.2020.11.02

Dorst, W., Glohr, C., Hahn, T., Knafla, F., Lenk, K., Meyerholt, U. et al. (2015). Umsetzungs strategie Indistrie 4.0. In Wissen managen in Staat und Verwaltung (163-172). https://doi.org/10.5771/9783845267913-163

Drewniak, M., \& Gabryś, M. (2017). Dynamics of a double physical pendulum with magnetic interaction. In Vibration, Control and Stability of Dynamical Systems (559-570). https:/ / doi.org/10.1007/978-3-030-15857-6

ECLAC (2020a). CEPALSTAT. Databases and Statistical Publications. https://cepalstatprod.cepal.org/cepalstat/tabulador/ConsultaIntegrada.asp?idIndicador=1\&idioma $=\mathrm{i}$

ECLAC (2020b). Preliminary overview of the economies of Latin America and the Caribbean.

Fettermann, D.D.C., Sá Cavalcante, C.G., Tortorella, G.L., \& de Almeida, T.D. (2018). How does Industry 4.0 contribute to operations management? Journal of Industrial and Production Engineering, 35(4), 255-268. https://doi.org/10.1080/21681015.2018.1462863

Frank, A.G., Dalenogare, L.S., \& Ayala, N.F. (2019). Industry 4.0 technologies: Implementation patterns in manufacturing companies. International Journal of Production Economics, 15-26. https://doi.org/10.1016/j.ijpe.2019.01.004

Gallivan, M., \& Srite, M. (2005). Information technology and culture: Identifying fragmentary and holistic perspectives of culture. Information and Organization, 15, 295-338. https://doi.org/10.1016/j.infoandorg.2005.02.005

Ganju, K.K., Pavlou, P.A., \& Banker, R.D. (2016). Does information and communication technology lead to the well-being of nations? A country-level empirical investigation. MIS Quarterly, 40(2), 417-430.

Gawankar, S.A., Gunasekaran, A., \& Kamble, S. (2020). A study on investments in the big data-driven supply chain, performance measures and organisational performance in Indian retail 4.0 context. International Journal of Production Research, 58(5), 1574-1593. https://doi.org/10.1080/00207543.2019.1668070

Gebauer, H., Edvardsson, B., \& Bjurko, M. (2010). The impact of service orientation in corporate culture on business performance in manufacturing companies. Journal of Service Management, 21(2), 237-259. https://doi.org/10.1108/09564231011039303

Ghobakhloo, M. (2018). The future of manufacturing industry: A strategic roadmap toward Industry 4.0. Journal of Manufacturing Technology Management, 29(6), 910-936. https:/ / doi.org/10.1108/JMTM-02-2018-0057

Global Business Reports (2019). Peru mining 2019 Pre-Release II. Available at: http://search.ebscohost.com/login.aspx? direct $=$ true $\& \mathrm{db}=$ aps\&AN $=138330421 \& \mathrm{amp} \% 0$ Alang $=\mathrm{pt}$-pt\&site $=$ eds-live \&authtype $={ }_{\text {sSO }}$

Global Entrepreneurship Monitor (2019). Global entrepreneurship monitor 2019/2020 global report.

Grzybowska, K., \& Lupicka, A. (2017). Key competencies for Industry 4.0. Economics and Management Innovations, 1(1), 250-253. https://doi.org/10.26480/icemi.01.2017.250.253

Gupta, M., \& George, J.F. (2016). Toward the development of a big data analytics capability. Information and Management, 53(8), 1049-1064. https://doi.org/10.1016/j.im.2016.07.004

Hair, J., Black, W., Babin, B., \& Anderson, R. (2010). Multivariate Data Analysis (7th ed.) Prentice Hall.

Hasan, H., \& Ditsa, G. (1999). The impact of culture on the adoption of IT. Journal of Global Information Management, 7(1), 5-15. https://doi.org/10.4018/jgim.1999010101

Haseeb, M., Hussain, H.I., Ślusarczyk, B., \& Jermsittiparsert, K. (2019). Industry 4.0: A solution towards technology challenges of sustainable business performance. Social Sciences, 8(5). https://doi.org/10.3390/socsci8050154

He, M., \& Lee, J. (2020). Social culture and innovation diffusion: A theoretically founded agent-based model. Journal of Evolutionary Economics, 30(4), 1109-1149. https://doi.org/10.1007/s00191-020-00665-9

Hoffman, N., \& Klepper, R. (2000). Assimilating new technologies: The role of organizational culture. Information Systems Management, 17(3), 36-42. https://doi.org/10.1201/1078/43192.17.3.20000601/31239.6 
Hofmann, E., \& Rüsch, M. (2017). Industry 4.0 and the current status as well as future prospects on logistics. Computers in Industry, 89, 23-34. https:/ / doi.org/10.1016/j.compind.2017.04.002

Hofstede Centre (2021). Hofstede insights. Compare Countries. Available at: https://www.hofstedeinsights.com/product/compare-countries/

Hofstede, G. (1980). Culture's Consequences: International Differences in Work Related Values. Sage.

Hofstede, G. (1983). National cultures in four dimensions. A research-based theory of cultural differences among nations. International Studies of Management \& Organization, 13(1-2), 46-74.

Hofstede, G. (2001a). Culture's Consequences: Comparing values, behaviors, institutions and organizations across cultures. Sage.

Hofstede, G. (2001b). Culture's Consequences: International Differences in Work-Related Values. CA: Sage.

Hofstede, G. (2011). Dimensionalizing cultures: The Hofstede model in context. Online Readings in Psychology and Culture, 2(1), 1-26. https://doi.org/http://dx.doi.org/10.9707/2307-0919.1014

Hofstede, G. (2013). Replicating and extending cross-national value studies: Rewards and pitfalls-An example from Middle East studies. Academy of International Business Insights, 13(2), 5-7. Available at: http://geerthofstede.com/wp-content/uploads/2016/07/Replicating-and-Extending.pdf

Hofstede, G., Hofstede, G.J., \& Minkov, M. (2010). Cultures and organizations. Software of the mind. Intercultural cooperation and its importance for survival. Mc Graw Hill.

Hoyle, R.H. (2015). Handbook of structural equation modeling. The Guilford Press.

Huang, F., Teo, T., Sánchez-Prieto, J.C., García-Peñalvo, F.J., \& Olmos-Migueláñez, S. (2019). Cultural values and technology adoption: A model comparison with university teachers from China and Spain. Computers and Education, 133, 69-81. https://doi.org/10.1016/j.compedu.2019.01.012

IBM, C. (2020). IBM SPSS statistics for windows, version 25.0. IBM Corp.

Kamble, S., Gunasekaran, A., \& Dhone, N.C. (2020). Industry 4.0 and lean manufacturing practices for sustainable organisational performance in Indian manufacturing companies. International Journal of Production Research, 58(5), 1319-1337. https://doi.org/10.1080/00207543.2019.1630772

Karahanna, E., Evaristo, R., \& Srite, M. (2001). Methodological issues in MIS cross-cultural research. Journal of Global Information Management, 10(1), 48-55. https://doi.org/10.4018/jgim.2002010105

Kayalvizhi, S., Amirtha Sughi, D., \& Divyalakshmi, R. (2019). Automation in manufacturing and retail industry using smart labels. International Journal of Advanced Science and Technology, 28(12), 450-459.

Kirkman, B.L., Lowe, K.B., \& Gibson, C.B. (2017). A retrospective on culture's consequences: the 35-year journey. Journal of International Business Studies, 48(1), 12-29. https://doi.org/10.1057/s41267-016-0037-9

Lasi, H., Fettke, P., Kemper, H.G., Feld, T., \& Hoffmann, M. (2014). Industry 4.0. Business and Information Systems Engineering, 6(4), 239-242. https://doi.org/10.1007/s12599-014-0334-4

Lee, C., Huang, G.-H., \& Ashford, S.J. (2018). Job insecurity and the changing workplace: Recent developments and the future trends in job insecurity research. Annual Review of Organizational Psychology and Organizational Behavior, 5(1), 335-359. https://doi.org/10.1146/annurev-orgpsych-032117-104651

Lee, S., Lee, D., Kim, S., \& Lee, G. (2017). Systems and organizational performance: Evidence from Korea and Japan. The Journal of Applied Business Research, 33(3), 521-538.

Liao, Y., Deschamps, F., Loures, E. de F.R., \& Ramos, L.F.P. (2017). Past, present and future of Industry 4.0 - a systematic literature review and research agenda proposal. International Journal of Production Research, 55(12), 3609-3629. https://doi.org/10.1080/00207543.2017.1308576

Luo, Y., Zhang, H., \& Bu, J. (2019). Developed country MNEs investing in developing economies: Progress and prospect. Journal of International Business Studies, 50(4), 633-667. https://doi.org/10.1057/s41267-019-00230-y 
Luthra, S., \& Mangla, S.K. (2018). Evaluating challenges to Industry 4.0 initiatives for supply chain sustainability in emerging economies. Process Safety and Environmental Protection, 117, 168-179.

https://doi.org/10.1016/j.psep.2018.04.018

Markova, E.S., Zyuzina, N.N., \& Krovopuskov, P.A. (2021). Digital economy and Industry 4.0: Russia's developmentt trends. International Transaction Journal of Engineering, Management, \& Technologies, 12(3), 1-13. https://doi.org/10.14456/ITJEMAST.2021.54

Martí, J., Alguacil, M., \& Orts, V. (2017). Location choice of Spanish multinational firms in developing and transition economies. Journal of Business Economics and Management, 18(2), 319-339.

https://doi.org/10.3846/16111699.2015.1013980

Mazali, T. (2018). From industry 4.0 to society 4.0, there and back. AI and Society, 33(3), 405-411. https://doi.org/10.1007/s00146-017-0792-6

McKinsey Global Institute (2019). Latin America's missing middle. Rebooting inclusive growth. www.mckinsey.com/mgi

Ministerio de la Producción (2021). Startup Perú. Startups Beneficiarias. https://www.start-up.pe/

Minkov, M. (2018). A revision of Hofstede's model of national culture: Old evidence and new data from 56 countries. Cross Cultural and Strategic Management, 25(2), 231-256. https://doi.org/10.1108/CCSM-03-2017-0033

Minkov, M., \& Hofstede, G. (2011). The evolution of Hofstede' s doctrine. Cross Cultural Management: An International Journal, 18(1), 10-20. https://doi.org/10.1108/13527601111104269

Moon, H.C., \& Lee, D. (2004). The competitiveness of multinational firms: A case study of samsung electronics and Sony. Journal of International and Area Studies, 11(1), 1-21.

Muafi, \& Kusumawati, R.A. (2020). Strategic consensus on organizational performance: A contingency approach of organizational culture and isomorphic pressure. Journal of Industrial Engineering and Management, 13(2), 352-370. https://doi.org/10.3926/jiem.2480

Načinović Braje, I., Klindžić, M., \& Galetić, L. (2019). The role of individual variable pay in a collectivistic culture society: an evaluation. Economic Research-Ekonomska Istrąivanja, 32(1), 1352-1372.

https://doi.org/10.1080/1331677X.2018.1559073

Nascimento, D.L.M., Alencastro, V., Quelhas, O.L.G., Caiado, R.G.G., Garza-Reyes, J.A., Lona, L.R. et al. (2019). Exploring Industry 4.0 technologies to enable circular economy practices in a manufacturing context: A business model proposal. Journal of Manufacturing Technology Management, 30(3), 607-627. https://doi.org/10.1108/JMTM-032018-0071

Powell, T. (1992). Organizational alignment as competitive advantage. Strategic Management Journal, 13(2), 119-134.

Quezada, L.E., Chiu, A.S.F., Gouvea da Costa, S.E., \& Tan, K.H. (2017). Operational excellence towards sustainable development goals through Industry 4.0. International Journal of Production Economics, 190, 1-2.

https://doi.org/10.1016/j.ijpe.2017.06.014

Raykov, T., \& Marcoulides, G.A. (2006). A first course in structural equation modeling (2nd ed.). Psychology Press.

Rojas, R.R. (2019). Cultural influences on Latin American perceptions of inclusion and diversity. International Journal of Organizational Diversity, 19(1), 45-61. https://doi.org/10.1007/978-3-030-35419-0_3

Roy, D. (2020). Formulation of Hofstede's global cultural dimension index (HGCDI): A cross-country study. Journal of Transnational Management, 25(3), 195-224. https://doi.org/10.1080/15475778.2020.1765715

Rugman, A.M., Oh, C.H., \& Lim, D.S.K. (2012). The regional and global competitiveness of multinational firms. Journal of the Academy of Marketing Science, 40(2), 218-235. https://doi.org/10.1007/s11747-011-0270-5

Saad, G.B., \& Abbas, M. (2018). The impact of organizational culture on job performance: A study of Saudi Arabian public sector work culture. Problems and Perspectives in Management, 16(3), 207-218.

https://doi.org/10.21511/ppm.16(3).2018.17 
Salehan, M., Kim, D.J., \& Lee, J.N. (2018). Are there any relationships between technology and cultural values? A country-level trend study of the association between information communication technology and cultural values. Information and Management, 55(6), 725-745. https://doi.org/10.1016/j.im.2018.03.003

Shamim, S., Cang, S., Yu, H., Li, Y., Chen, L.Y., \& Yao, X. (2019). How firms in emerging economies can learn Industry 4.0 by extracting knowledge from their foreign partners? A view point from strategic management perspective. International Conference on Advanced Mechatronic Systems, ICAMechS (390-395). https://doi.org/10.1109/ICAMechS.2019.8861622

Shen, W., \& Norrie, D.H. (2001). Agent-based intelligent manufacturing systems: A state-of-the-art survey. Knowledge and Information Systems, 1(2), 129-156.

Singh, R.K., Kumar, P., \& Chand, M. (2019). Evaluation of supply chain coordination index in context to Industry 4.0 environment. Benchmarking. https://doi.org/10.1108/BIJ-07-2018-0204

Singh, S., Cervai, S., \& Kekäle, T. (2016). Workplace learning in emerging economies. Journal of Workplace Learning, 26(8). Emerald Publishing Limited.

Slimbach, R. (1993). The Transcultural Journey. The Interdisciplinary Journal of Study Abroad, 205-230.

Sophie, R., Pellerin, R., Bellemare, J., \& Perrier, N. (2020). A business process and portfolio management approach for Industry 4.0 transformation. Business Process Management Journal, 505-528. https://doi.org/10.1108/BPMJ-05-20200216

Srisathan, W.A., Ketkaew, C., \& Naruetharadhol, P. (2020). The intervention of organizational sustainability in the effect of organizational culture on open innovation performance: A case of thai and chinese SMEs. Cogent Business and Management, 7(1), 1-28. https://doi.org/10.1080/23311975.2020.1717408

Srite, M. (2006). Culture as an explanation of technology acceptance difeerences: An empirical investigation of chinese and us users. Journal of Information Systems, 14(1), 5-26.

Stachová, K., Papula, J., Stacho, Z., \& Kohnová, L. (2019). External partnerships in employee education and development as the key to facing Industry 4.0 challenges. Sustainability, 11(2). https://doi.org/10.3390/su11020345

Stock, T., \& Seliger, G. (2016). Opportunities of sustainable manufacturing in Industry 4.0. Procedia CIRP, 40, 536-541. https://doi.org/10.1016/j.procir.2016.01.129

Stock, T., Obenaus, M., Kunz, S., \& Kohl, H. (2018). Industry 4.0 as enabler for a sustainable development: A qualitative assessment of its ecological and social potential. Process Safety and Environmental Protection, 118, $254-267$. https://doi.org/10.1016/j.psep.2018.06.026

Taddeo, R., Simboli, A., Di Vincenzo, F., \& Ioppolo, G. (2019). A bibliometric and network analysis of lean and Clean(er) production research (1990/ 2017). Science of the Total Environment, 653, 765-775.

https://doi.org/10.1016/j.scitotenv.2018.10.412

Tarhini, A., Hone, K., \& Liu, X. (2015). A cross-cultural examination of the impact of social, organisational and individual factors on educational technology acceptance between British and Lebanese university students. British Journal of Educational Technology, 46(4), 739-755. https://doi.org/10.1111/bjet.12169

Tarhini, A., Hone, K., Liu, X., \& Tarhini, T. (2017). Examining the moderating effect of individual-level cultural values on users' acceptance of e-learning in developing countries: A structural equation modeling of an extended technology acceptance model. Interactive Learning Environments, 25(3), 306-328.

https://doi.org/10.1080/10494820.2015.1122635

Tortorella, G.L., Cawley Vergara, A.M., Garza-Reyes, J.A., \& Sawhney, R. (2020). Organizational learning paths based upon industry 4.0 adoption: An empirical study with Brazilian manufacturers. International Journal of Production Economics, 219, 284-294. https://doi.org/10.1016/j.ijpe.2019.06.023

Tortorella, G., Miorando, R., Caiado, R., Nascimento, D., \& Portioli Staudacher, A. (2018). The mediating effect of employees' involvement on the relationship between Industry 4.0 and operational performance improvement. Total Quality Management and Business Excellence, 0(0), 1-15. https:/ / doi.org/10.1080/14783363.2018.1532789 
Usoro, A., \& Abiagam, B. (2018). Culture effect on knowledge management adoption in Nigerian hospitality industry. VINE Journal of Information and Knowledge Management Systems, 48(3), 314-332.

https://doi.org/10.1108/VJIKMS-11-2017-0080

Van Muijen, J.J., \& Koopman, P.L. (1994). The influence of national culture on organizational culture: A comparative study between 10 countries. European Work and Organizational Psychologist, 4(4), 367-380. https://doi.org/10.1080/13594329408410496

Vrânceanu, C.A., \& Iorgulescu, M.-C. (2016). A look at Hofstede’s cultural dimensions in two service sectors from Romania. Amfiteatru Economic, 18(10), 875-884.

Wang, S., Wan, J., Li, D., \& Zhang, C. (2016). Implementing smart factory of industrie 4.0: An outlook. International Journal of Distributed Sensor Networks, 37, 517-527. https://doi.org/10.1155/2016/3159805

Wei, Z., Song, X., \& Wang, D. (2017). Manufacturing flexibility, business model design, and firm performance. International Journal of Production Economics, 193(28), 87-97. https://doi.org/10.1016/j.ijpe.2017.07.004

Weyer, S., Schmitt, M., Ohmer, M., \& Gorecky, D. (2015). Towards Industry 4.0 - standardization as the crucial challenge for highly modular, multi-vendor production systems. IFAC-PapersOnLine, 28(3), 579-584. https://doi.org/10.1016/j.ifacol.2015.06.143

Witkowski, K. (2017). Internet of things, big data, Industry 4.0 - innovative solutions in logistics and supply chains management. Procedia Engineering, 182, 763-769. https://doi.org/10.1016/j.proeng.2017.03.197

Wollschlaeger, M., Sauter, T., \& Jasperneite, J. (2017). The future of industrial alcohols. IEEE Industrial Electronics Magazine, 11(1), 17-27. https://doi.org/10.1109/MIE.2017.2649104

World Bank Group (2014). Mapping enterprises in Latin America and the Caribbean.

World Bank Group (2020). World Bank Group. World Bank Open Data. https://doi.org/10.1007/bf02930523

World Economic Forum (2019). The global competitiveness report.

World Intellectual Property Organization (2020). Global Innovation Index 2019. https://www.globalinnovationindex.org/gii-2016-report

Yadegaridehkordi, E., Nilashi, M., Shuib, L., Nasir, M.H.N.B., Asadi, S., Samad, S., \& Awang, N.F. (2020). The impact of big data on firm performance in hotel industry. Electronic Commerce Research and Applications, 40, 100921. https://doi.org/10.1016/j.elerap.2019.100921

Yunis, M., Tarhini, A., \& Kassar, A. (2017). The role of ICT and innovation in enhancing organizational performance: The catalysing effect of corporate entrepreneurship. Journal of Business Research, 1-13. https://doi.org/10.1016/j.jbusres.2017.12.030

Ziaei Nafchi, M., \& Mohelská, H. (2020). Organizational culture as an indication of readiness to implement Industry 4.0. Information, 11(3), 174. https://doi.org/10.3390/info11030174

Journal of Industrial Engineering and Management, 2021 (www.jiem.org)

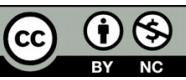

Article's contents are provided on an Attribution-Non Commercial 4.0 Creative commons International License. Readers are allowed to copy, distribute and communicate article's contents, provided the author's and Journal of Industrial Engineering and Management's names are included. It must not be used for commercial purposes. To see the complete license contents, please visit https://creativecommons.org/licenses/by-nc/4.0/. 